\title{
Mondá - mondta. A folyamatos és az egyszerü múlt idő konstruálási mintázatai 19. századi naplókban ${ }^{1}$
}

\section{Bevezetés}

A nyelvi tevékenység csakis a maga kontextusában érvényesül, ezért a leírásnak is ezt kell figyelembe venni. A múlt idők vizsgálata a szövegtípusnak és a szövegtípushoz kapcsolódó jellegzetes beszédhelyzeteknek, a beszélök interaktív és interszubjektív nyelvi tevékenységformáinak az együttes leírásával lehetséges.

Az alábbi tanulmány öt 19. századi, reformkori napló szövegében elemzi az egyszerü és az elbeszélő múlt idejü igealakok megoszlását. A vizsgálat a mond ige használatára korlátozódik. Az elemzés bemutatja, hogy a mond ige a naplókban túlnyomó többségben elbeszélő múlt időben konstruálódik meg, hogy kötőszós tartalomkifejtő összetett mondatok fömondataként, a mellékmondatban a mondás által újrakonstruált idézettel. A mond igének ez az erősen szubjektivizált használata a naplóbejegyzés szövegében episztemikus közvetlenséggel hozza be a naplószöveg egyik szereplöjének nyelvi tevékenységét, a beszéd vagy a naplóíró részvételével lezajlott beszélgetés átélö, részvételi, tanúsági felidézésével. A mond igének ez a meglehetősen következetes használata a felidézett kommunikációs helyzet és a naplóírás kommunikációs helyzete közötti szoros összefüggést mutatja, szemben a más jellegű eseményeknek a korpuszban gyakran egyszerü múlttal kifejezett temporalitásával.

Az itt vizsgált naplók művészi, irodalmi jellegét a jelen tanulmányban nem vizsgálom, jóllehet a különbségek nyilvánvalóak.

Az elbeszélő múlt (általában a magyar múltidők) történeti kutatása igen kiterjedt, és főképp a régebbi századokra (az ómagyar és a középmagyar korszakokra) összpontosít (lásd Abaffy 1992; Mohay 2018). A 19. századra a múlt idők rendszere fokozatosan átalakult, csak az elbeszélő és az egyszerü múlt idő maradt meg ténylegesen. Ezek használata és megoszlása folyamatosan változott. Egyrészt az elbeszélő múlt a század végére valóban eltünt a használatból (a szépirodalom területére lásd J. Soltész 1957). Másrészt - és ez az érdekesebb az alakulástörténetben - a két múlt idő funkcionális elkülönülése még egyszer megtörtént. Az elbeszélő múlt időt az írott szövegekben, ott is a választékosabb, tervezett szövegekben használtatották. Ennek a használatnak az egyik jellemzője a beszélő nézőpontjában az elbeszélő múlt által megjelenített közvetlen tapasztalatiság, az átélés, a szemtanúság volt, a másik ezzel szoros összefüggésben a folyamatosság, az elbeszélt esemény temporalitásának a múltból felidézett szimulációs folyamatos jelen ideje. Nem véletlen, hogy - legalábbis a jelen vizsgálat korpuszában, a naplókban - a kommunikációs igék az átlagnál jóval nagyobb mértékben jelennek meg elbeszélő múlt idős alakban. Ehhez a gyakorisághoz csak a létige hasonló múltbeli lehorgonyzása hasonlítható. Ezzel együtt is egyértelmü, hogy az 1830-as, 1840-es években írt naplókban sem következetes az elbeszélő múlt idő használata, még a kommunikációs igék tartományában sem.

1 A dolgozat elkészítését az NKFIH 129040 számú pályázata (A magyar nyelv igei konstrukciói. Használatalapú konstrukciós nyelvtani kutatás) támogatta. Köszönöm Csontos Nóra és Tátrai Szilárd gondos és segítő kiegészítéseit. 


\section{A korpusz}

A jelen tanulmányban a múlt idő szempontjából vizsgált naplók fő adatai a következők (a bibliográfiai leírásokat lásd a Források alatt).

Bártfay László kiadott naplója 1838. januárja és 1841 decembere között készült. A napló terjedelme 138 ezer szó, 980 ezer karakter szóközökkel. A mond ige adatai: mondám 68, mondá, monda 155, mondánk 2, mondák 9; mondtam 3, mondta (igekötővel is) 4; mondták 2. Elbeszélő múlt idős alak 234, egyszerü múlt idős alak 9.

Kölcsey Antónia naplója 1838. májusa és 1844. decembere között készült, nagyobb kihagyásokkal. A napló terjedelme 25600 szó, 162600 karakter szóközökkel. A mond ige adatai: monda 4, a mondá 29, mondám 2. Elbeszélő múlt idejü ragozott alak 36, egyszerü múlt idejü alak: mondta, mondtam, mondták összesen 6.

Kölcsey Ferenc Országgyülési naplója 1832. decembere és 1833. augusztusa között készült. A napló terjedelme 65 ezer szó, 428 ezer karakter szóközökkel. A mond ige adatai: mondám 5, mondád 1 , mondá, (igekötővel is) 12, mondánk 3 , mondák 22 , mondának 9. Elbeszélő múlt idős alak: 52, egyszerü múlt idejü alak: 0.

Slachta Etelka itt idézett naplója 1838. december és 1840 áprilisa között készült. A napló terjedelme 31 ezer szó, 214 ezer karakter szóközökkel. A mond ige adatai: mondám 23, mondá 120, mondánk 3, mondák 5; mondtam 2, mondta 4, mondtak 1, mondtuk 1, mondták 1, mondtak 1 . Elbeszélő múlt idős alak: 151, egyszerü múlt idejü alak: 10.

Tóth Péter naplójának itt vizsgált első részei 1836. júniusa és 1837. februárja között készültek (az 1984. évi kiadásban 1-152. oldal). A napló e szakaszának terjedelme 27 ezer szó, 170 ezer karakter szóközökkel. A mond ige adatai: mondám 35, mondá 69 , mond 4 (E/3. alak), mondánk 2, mondók 2, mondák 1; mondtam 5, mondta 2, mondott 1, mondtuk 3. Elbeszélő múlt idős alak: 113, egyszerü múlt idős alak: 10.

Az egyszerünek tủnő taxonómia meglehetősen egyértelmű képet mutat: az öt, habitusukban, társadalmi helyzetükben és íráshoz való viszonyukban erősen különböző naplóíró egységesen az elbeszélő múlt időt alkalmazza túlnyomó többségben a mond igével megkonstruált nyelvi szerkezetekben. Ez az arány más, itt nem említendö kommunikációs igék esetében is hasonló.

Az alábbiakban a mond ige két múlt idejü alakjának megoszlását, az elbeszélő múlt idő funkcióit a konstruálás kontextuális közegében mutatom be.

\section{A napló szövegtípusa}

Az irodalomtudomány, elsősorban a formalista elméletek sora a perifériára helyezte a napló müfaját. Mégis, főképp a 19. században, elsősorban a romantika irodalmi folyamataiban megnőtt a napló jelentősége (vö. Szegedy-Maszák 2002). Ez az alakulástörténet túllépett a szükebben vett irodalom hatókörén, az írás, az emlékezés, a dokumentálás és a nyelvi konstruálás olyan tevékenységformái alakultak ki - összhangban az európai folyamatokkal -, amelyek a személyiség nyelvi megkonstruálását, az események, reflexiók (például a belső feszültségek, válságok), érzések, 
tervek, álmok rögzítését valós és virtuális hálózatokban helyezi el. A napló az önreprezentáció és a naplóíróval összefüggésbe kerülő személyek és események, viszonyok beírásának a diszkurzusa.

A naplóírás személyes, ezért részben spontán, de egyúttal a tudatos megformálás nyelvi cselekvése. A napló monologikus, írott és tervezett szöveg, vagyis a beszélő (a naplóíró) egyedül beszél, sőt egyedül van a bejegyzés során, hiszen a naplóírás cselekedete az magánszférába tartozik. Ebben a magányhelyzetben a naplóíró jórészt tudatosan hozza létre szövegét, eldönti és kiválasztja, mit jegyez be, milyen nyelvezettel. A naplóíró saját kommunikációs teret és tevékenységi formát hoz létre. A napló alapegysége a bejegyzés. A bejegyzések szerkezete dátum szerint időrendi, általában napi egységekben. Fontos jellemző a folytonosság, a bejegyzések egymásra következése. „, [A] naplók általában a célelvüen elöre haladó vallomás és a töredékszerü följegyzéshalmaz végletei között helyezhetők el” (vö. Szegedy-Maszák 2002).

A napló jellegzetesen perspektivált: nem az események taxonómiája, hanem a naplóíró számára fontosak említése a meghatározó. A naplóíás referenciális és faktuális nyelvi tevékenység (nem képzeleti; lásd Z. Varga 2020: 330). A napló nézőpontszerkezetében egyrészt a saját beszélői nézőpont (a referenciális központ; vö. SandersSpooren 1997; Tátrai 2017: 940 kk.) állandóan érvényesül, a naplóíró beszél, döntően egyes szám első személyben. Másrészt e nézőpontszerkezetben a tudatosság szubjektuma hangsúlyosan a naplóíró, ő az információ forrása, ő felelős a beírtak hiteléért.

A naplóíró beszélő egyes szám első személyben szólal meg, ebből a referenciális központból konstruálja meg a beírandókat. Ez a beszédmód a monológ több jellegzetességét fölerősíti. A naplóíró alapvetően önmagához beszél, amikor saját magáról ír. A naplóbejegyzésre az itt vizsgált korpuszban eltérő mértékben jellemző az önreflexió, az események és viszonyok közvetlen tárgyias és reflexív följegyzése mellett. Az elbeszélő és az elbeszélt én közötti távolság változó; például Slachta Etelka naplójában a viszony igen közelinek látszik, hasonlóan Bártfay László szövegében is; míg Tóth Péter vagy Kölcsey Ferenc naplójában az erős személyes reflektáltság miatt is ez a távolság jelzetten nagyobb. Az alábbi részletben (mint másutt is) Kölcsey E/3. alakban szól saját magáról:

(1) A szatmári követ éppen e napra volt a nádor ebédjéhez meghiva; s érezvén, hogy midőn közügyet védelmez, akkor sohasem személyességből szokott kiindulni: önérzésébe leplezve jelent meg a haragvónak asztalánál. Tartott az ebéd; s azalatt, míg a vendégek feszes ruhákban, karddal oldalaikon s kalpaggal félkezeikben bajjal költék el az étkeket: a fenség komolyan üle székén, és sem tartós, sem hangos beszédbe nem ereszkedék. Felkelénk, s a mellékteremben sorban várók a hercegi gazdát egyik vendégétöl másikig rövid beszélgetés közben járdáim. S uraságod társa hol van? kérdé a szatmári követet, reá kerülvén a sor. Serenissime! ő betegebb, mintsem megjelenhetett volna. (Kölcsey Ferenc, 1833. május 23.)

A naplóbejegyzés szubjektivizált (minden E/1. beszéd az valamilyen mértékig), de egyúttal objektivizált, amennyiben a saját magáról mint az események, folyamatok 
szereplöjéről ír (ehhez lásd Langacker 2006; Kugler 2013). A szubjektivizáló részek (például az E/1. alakú bejegyzések és az implicit értékelő beszélöi jelenlét) gyakorisága a naplóbejegyzés általában rövid, tömör jellegének is eredménye: a naplóban kimondatlan, bennfoglalt, sugallt tartalmak is vannak, amelyek szubjektivizációs szerkezetekben válnak elérhetővé (ha egyáltalán) a napló külső olvasója számára.

A fenti rövid leíráshoz hangsúlyosan hozzátartozik, hogy ugyanakkor a napló elsődlegesen nem nyilvánosságnak szánt írásmü, az itt tárgyalt, az 1830-as, 1840-es években írt naplók bizonyosan nem azok (ezzel a diszkurzív alapállással kerül szembe az írói napló a 20. század első felében, és nyíltan a világhálón a blog). A naplóíró önmagához szól, befelé fordul, a magán-, sőt intimszférában beszél bizalmasan, de tudja, hogy ez óhatatlanul kifelé is irányul, mások is elolvashatják. Személyes, ezért részben spontán, de egyúttal gondosan megformált írás.

Főképp a későbbi jövőre tekintve a nyilvánossá válás (nem feltétlenül nyíltan) remélt összetevő is a naplóírás tevékenységében. Mennyire nyilvános vagy magánbeszéd? Hiszen a belső beszéd, a magánbeszéd is a másikra irányul (ahogy azt Bahtyin kimutatta), a napló esetében a megkonstruált másik, a naplóírótól elkülönböző, elképzelt, implicit olvasóra.

A naplóírás már a 19. század első felében nem puszta eseményjegyzék, hanem az autonóm személyiség megkonstruálása, a művelődéssel, az írás személyes müvelésével, egy tudottan diszkurzív rendben. Az itt vizsgált korszakban, a magyar polgárosodás egyik kezdeti jelentős szakaszában ez a mozzanat hangsúlyosan jelen van.

Az itt vizsgált naplókban a naplóíró reflexív és önreflexív interszubjektív jellemzőit az alábbiakban lehet összefoglalni. Ezek a tényezők a metapragmatikai tudatosság jelölőivel együtt jelentős szerepet játszanak a bejegyzések deiktikus igeidőszerkezetének alakulásában.

Bártfay László naplójában nincs különösebb utalás a lehetséges olvasóra, valójában a naplóíró önmagára sem reflektál. A napi bejegyzések rövid mondatszerkezetü, gyors eseményrögzítések, amelyek magukra az eseményekre és az azokkal kapcsolatos naplóírói reflexiókra korlátozódnak.

Kölcsey Antónia számos alkalommal utal saját naplóvezetésére, viszonyára naplójához. Továbbá naplójában észlelhető az elképzelt olvasóhoz fordulás az erős önreflexióval együtt. A nyelvi megformálás és a helyes viselkedés közös (nemesi és polgári) normáinak megfelelés visszatérő téma, ez az íratlan normarendszer mint közösségi intézmény, valamint a közvetlen környezet (a család, a szülők, Kölcsey Ferenc, Szemere Pál) rendszeresen említett orientáló minta. Például:

(2) Ma ollyan rosz napom volt. Apám nagyon haragudott rám és nagyon megszidott. Vigyázatlan voltam ugyan, de tudatlanságból. Horváth Gábor szinte egy hétig volt most itt, 's ez idő alatt mindég kérte emlékkönyvemet, hogy vihesse el és rajzolhasson bele valami tájképet. Én nem akartam adni könyvemet, de ő annyit kérte, hogy végtére oda ígértem egy pár hétig, míg a' rajzot elkészíti, mert már rég is óhajték bele egyet. Mikor elment, Apám nagy haraggal hozzám jön 's szid és fedd hogy mikép merem emlékköny- 
vemet egy ide- gennek oda adni, 's megmagyarázza hogy mily illetlen ez 's hogy én e' tettel nagyon hibáztam. (Kölcsey Antónia 1843. október 1.)

Kölcsey Ferenc az Országgyülési naplóban rendszeresen képviselötársaihoz fordul (,uraim”), illetve a többnyire idealizált képviselőhöz vagy azok csoportjaihoz:

(3) Zörgessetek, mond az evangyéliom, s megnyittatik. A zörgetés íme megtörtént; $\mathrm{s}$ ha nem talál megnyittatni? Akkor uraim kinn maradunk, mert oly ajtó van elöttünk, melyet betörni - nem szabad" [(Kölcsey Ferenc 1833. március 30.]).

Hasonló gyakorisággal fordul a feltételezett olvasóhoz, olvasókhoz („Emlékezzetek Révaira" [1833. április 1.]). Ez az olvasó szintén egyfajta típus: a müvelt, olvasni tudó, szöveget értő és a nemzet ügye iránt elkötelezett személy. Kölcsey önmagát is megszólítja, többször is: „Édes naplós uram, mire egyszer e bölcselkedés?” (1833. június 1.).

Slachta Etelka naplójában nincs különösebb utalás a lehetséges olvasóra, valójában a naplóíró önmagára sem reflektál. A napi bejegyzések rövid mondatszerkezetü, gyors eseményrögzítések, amelyek magukra az eseményekre és az azokkal kapcsolatos naplóírói reflexiókra korlátozódnak, saját értelmezéseire és érzelmeire, de csak az esemény közbeni megállapítások szintjén, utólagos elemzések nem olvashatók arról, miképp alakult a viszonya egyes emberekkel a társasági élet adott pillanatában (pl. udvarlás, flörtölés közben). Például:

(4) Első cotillont Jenik Marival táncolá, az egyik figuránál (Damen und Männer Ronde) egyre kért, a legtüzesebben, választanám őt, mit éppen nem tevék, de a jövő figurában s még egy párszor őt választám. Jenik Mari igen udvariasan köszöntött $\mathrm{s}$ a leghízelgőbben dicséré játékomat. Falkenhausen élet-halálra udvarol nékem. Kért és nyert is engedelmet visszajövetelekor (Sziléziába utazik) személyesen tudakozódni, hogy vagyok. Kérdé, nem hiányzik-e senki ismerőseim közt. Én persze előbb Derrát, később Rollet s csak találgatva Fischert nevezém. Ö mondá, hogy ennél szállt fel. Felhúzott vele; mondám, hogy semmi sincs a dologban, hogy Jenik Marinak udvarol, természetesnek is találom, mert mindig vele énekel. (Slachta 1839. február 2.)

Tóth Péter naplójában nincs nyíltan elképzelt olvasó, ugyanakkor a sárospataki korszakból származó naplóbejegyzésekben többször ír arról, hogy a baráti kör tagjai rendszeresen olvasták egymás naplóját, főképp a megelőző napokról szóló részeket, és utóbb élőszóban reflektáltak is a bejegyzésekre. Továbbá több helyen saját naplóírására és naplószövegére reflektál, például:

(5) „Ma csütörtök van; mindig vártam időt, melyben én ezt [az előző bekezdésben foglaltakat] hosszan kifejtem, de látom, hiába várok" (Tóth 1836. télelö [december] 5. ). 
A napló itt összefoglalt szövegtani jellemzése egyesíti azt a két nézöpontot, amely a szövegtani kutatásokban, közelebbről a szövegtipológiai vizsgálatokban kialakult az elmúlt néhány évtizedben. Az első nézőpont a szöveg szerkezetének, pontosabban a szöveg vehikulumának és műveleti (vagyis megértési) szerkezetének a funkcionális nyelvészeti leírása (vö. Tolcsvai Nagy 2008). A második nézőpont a műfaj terminussal megnevezett megközelítés, amely a szöveg típusát a kommunikációs tevékenység, a beszélői cselekvések kontextuális, szituációs oldala, forgatókönyve felől közelíti meg (vö. Stukker-Spooren-Steen 2016; Simon 2017; Taavitsainen 2004).

\section{A napló időszerkezete}

A naplóíró mindig jelen időben beszél. Ez a körülmény természetesen nem korlátozódik a naplóra. A naplóbejegyzés alaphelyzete azonban már eleve azt a temporális viszonyt idézi fel, amelyben a naplóíró beszédének (a bejegyzésnek) a most-ja az a nap, amelynek korábbi eseményeit rögzíti.

A naplóra a kváziegyidejüség jellemző (Z. Varga 2020: 332), az időbeli közelség az élményhez. Ezt a naplóíró is tudja, és a napló olvasója számára is egyértelmü: a mostba mint egyetlen napba beletartoznak az egész napi események és annak a végén maga a bejegyzés cselekedete. A bejegyzésekben mint szövegegységekben a naplóíró ezt a közelséget mégis kettéválasztja időben: a napi események temporális lehorgonyzásának nyelvi jelölője a deiktikus igei múlt idő. A bejegyzés aktusa viszont hangsúlyosan folyamatos jelen időben történik az elbeszélt eseményekhez idejéhez viszonyítva, még akkor is profiláltan, ha ez a jelen legtöbbször jelöletlen nyelvileg.

A bejegyzések egymást követő sora többszörösen temporális. A napló szerkezetében nincs teleológia, nincs végső lezártság (Z. Varga 2020: 332), a bejegyzés idején nem lehet feltétlenül tudni, mi jön a következő napon vagy napokban. Minden nappal mint időegységgel újra konstruálódik a bejegyzés cselekvésformája, a közvetlen múlt eseményeinek elbeszélése a nap végi jelenben. A naplóíró benne áll az esemény(ek)ben, minden bejegyzésben újraformálódik a nézőpontszerkezet és az időstruktúra.

A rögzítés a beírt eseményt és a beírás eseményét, annak időbeli egymásra következését egyúttal a különidejü események (beírt esemény és a beírás eseménye) egyidejüségének hatását is kelti. Az itt vizsgált öt napló temporális változatai itt mutatkoznak meg. Az alapbeállítás szerinti diszkurzív viszonyban a naplóíró az írás jelenében beszél, általában jelöletlenül, a leírt esemény leírásának időbeli aktusára többnyire nincsen explicit utalás. Bártfay László naplójában ellenben sok jelen idejü utalás van a bejegyzés idejének időjárására, mindig a bejegyzés végén (például „Az idő sáros, lucskos. Az est csillagtalan, ködös" [Bártfay, 1839. február 19.]). Kölcsey Ferenc gyakran tér ki pozsonyi szállásának a körülményeire, illetve arra, hogy a bejegyzés idején milyen körülmények között, milyen szellemi és hangulati állapotban van.

A napló folyamatos, de szakaszos, egymásra következő írása a naplóíró számára az események elmondásával együtt az idő elbeszélése és az idő egzisztenciális átélése, napi egységekre bontva, de egyúttal azon túl is nyúlva. A feljegyzett események 
adják a tapasztalati tér lényegi összetevőit, egyúttal mindig megnyitva a még nem ismert jövő elváráshorizontját (vö. Koselleck 2003: 401-30).

Mindez interaktív és interszubjektív helyzetben megy végbe: a naplóíró tud arról, hogy szövegében ő a tudatosság szubjektuma, tőle származik az információ, ő a hitelesség forrása, a saját korábbi és várható későbbi bejegyzései összefüggéseiben és egymásra következésében. Saját naplójának olvasója is egyben, akár csak visszaemlékezve beírt részletekre, és ez a befogadás nyilvánvalóan az olvasó saját életének jelen időben folyó értelmezésére is hatással van.

A napló írója elképzelt olvasónak ír. Az olvasó és a napló írója mint olvasója is magát a befogadást, az olvasást is időben teheti meg. Az olvasás ideje, időszerkezete nem egyezik a beírás napi szekvenciájú időszerkezetével, de rokon vele, az olvasó is érzékeli az időbeli egymásra következést. Egy-egy bejegyzés nem csupán dátumhoz kötődik, hanem az elbeszélt események és reflexiók elképzelt, felidézett időtartamához és befogadási időtartamához. A napló írásában és olvasásában a bejegyzések szekvenciális jellegében nyíltan érvényesül a megértett és megértő idő egymáshoz való viszonya (Langacker 2008: 79).

Az itt vizsgált korpusz öt naplójának bejegyzései a múlt idők tekintetében igen vegyesek. Nemcsak az egyes szerzők naplóiban nem következetes az elbeszélő múlt alkalmazása, hanem az öt naplót egy korszak, egy évtized nyelvtörténeti keretében vizsgálva sem. Kölcsey Antónia naplójában nagyobb a rendszeresség (nagy gyakorisággal az adott napról szóló bejegyzés általános érvényü, egyszerű múlt idős kezdő részét a személyes epizódok elbeszélő múlt idős alakjai követik). Kölcsey Ferenc országgyülési naplójában az elbeszélő múltat általában (de nem kizárólagosan) a személyesen átélt jelenetek leírására használja, és az egyszerü múltat inkább a napi eseményekhez képest korábbi történésekre. Bártfay László naplója erős vegyülékességet mutat: vannak (majdnem) tisztán egyszerú múlt idős és (majdnem) tisztán elbeszélő múlt idős hosszabb szövegrészek, teljes bejegyzések, függetlenül az elbeszélt esemény személyes érintettségétől. Tóth Péter naplójában szintén a személyesen átélt és közvetlen szemtanúsággal elmondott részekre jellemző az elbeszélő múlt, de ugyanilyen jellegủ beszámolórészletek jelentős mennyiségben készültek egyszerủ múlttal is. Slachta Etelka naplójában igen gyakori az elbeszélő múlt a kommunikációs igékkel és a mozgásigékkel, de más tekintetben az egyszerü múlt használata nem tekinthető szabályszerünek.

Az általános képet két idézettel érdemes illusztrálni, mindkettő Bártfay László naplójából vett részlet. A (16) bejegyzés egyszerü múlt időben van megfogalmazva, leszámítva a valék létigei alakot (amely mellett egy sorral lejjebb a voltam alak is megjelenik). Ebben a részletben a naplóíró saját napi tevékenységének epizódjait rögzíti rövid mondatokban. A (7) bejegyzés ellenben legnagyobb részt elbeszélő múltban íródott, holott annak első kétharmada nem is közvetlenül a saját tevékenyégéröl számol be, hanem munkaadója gyermekének a keresztelöjéről. A bejegyzés temporális perspektiváltsága megváltozik a „Midőn szobámba jövék vissza” kezdetü résztől. Innentől az objektivizáló beszédmód ismét dominál, az elbeszélő múlt idejü igékkel együtt is. A rövid mondatok itt a közvetlenül tapasztalt egymásra következést is kifejezik. 
(6) 3dikán, Szerdán. - A' Gróf bejövén Fótrul hozzá mentem 's nála valék délig. Délután Szemere jött hozzám; bevégeztük fordítását (Der Neffe als Onkel, Schillertől) voltam a' játékszinben. Havazott. Az ég egész nap borult. (Bártfay, 1838. január 3.)

(7) 19d; kedd. - Délelőtt keveset tehettem, mivel a' Grófi újszülött ma kereszteltetvén hol egy hol más részről el valék foglalva. Gróf Károlyi István a' keresztatya: de ő maga nem lévén itt, képviselője Gr[óf]. Szapáry Antal volt, a’ Grófok' sógora. Keresztelé: Feichtinger Prépost 's a' város' plebánusa. A' kisded ezen neveket nyeré: Victor, Pál, István, Antal, Simon. A' szertartáson, melly a' kis ebédlőben mene végbe, jelen volt: Gr[óf]. Szapáry Ant[al]. mint helyettes; Gr[óf]. Sztáray Albertné, Sztáray Julie és Sophie Gr[óf]. kisasszonyok; Gr[óf]. ZichyÖdönné szül. Odescalchi H[e]r[ce]gné; feleségem; Radnics Agnes; Emma, a' Kindsmädchen. Továbbá: a' Gróf; a' kis Grof Sztáray László; Hörmann; én; Jósa, és a' Komornok Giovanne Rio. - A' keresztelés 12 óra előtt történt. Ki osztogattam az ajándékokat. - A' gyermeket a' bábaasszony tartá. - Midőn szobámba jövék vissza, itt találám Szemerét, kinek ma születésnapja. Nálunk ebédelt Vörösmarty. Délután egy képet illeszték be a’ rámába. Olvastam a' Carthausit. Meglátogatott Pap Endre 's ő hozá a' hírt, hogy Kossuth 3 évre van elitélve. Voltam színházba. Az idő sáros, lucskos. Az est csillagtalan, ködös. Bevettem camomillát (Bártfay, 1839. február 19.)

Az öt naplóban az egyszerü múlt idő használatával a naplóíró az időbeli referenciakeretben objektivizálva, időben távolabbról konstruálja meg az egyes eseményeket. A bejegyzés ideje és a napközbeni események egyenként lezárt ideje közötti egyértelmü eltérés meghatározó. A beszélő önmagát kívülröl látja korábbról, a többi szereplővel azonos tárgyiasító időbeli távolságból.

Az elbeszélő múlt idő használatával a naplóíró átélt folyamatként, nagyobb mértékü szubjektivizációval konstruálja meg az eseményeket az időbeli referenciakeretben. A bejegyzés időfolyamata közvetlen(ebb) megfelelésben van az elbeszélt eseményekkel, amelyek epizódonként nem válnak szét élesen.

Az így elkülönített két fö típus azonban több változatban valósul meg. Ezekben a változatokban a két múlt idő közötti funkcionális különbség skalárisan változik, a skála egyik szélső tartományában erősen különböznek, a másik tartományában közel vannak egymáshoz.

\section{A mond a naplóbejegyzésekben}

A mond ige a magyarban alakilag tranzitív aktív ige. A fó sematikus figurák (vonzatok) a következők: valaki mond valamit valakinek (ehhez lásd Csontos 2012: 198-9). Az elsődleges figura (trajektor) aktív emberi cselekvő, aki mond valamit, vagyis a beszélő, szándékosan cselekvő ágens. Mondatbeli kidolgozása jellegzetesen alany. Az egyik másodlagos figura (landmark) a mondás tartalma, passzív téma szemantikai szerepben. Mondatbeli kidolgozása jellegzetesen grammatikai tárgy vagy tárgyi 
utalószó és az azt kidolgozó tartalomkifejtő tárgyi mellékmondat, idézetként. A másik másodlagos figura (landmark) a mondás hallgatója, experiens vagy beneficiens, mondatbeli kidolgozása jellegzetesen datívuszos határozó. A trajektor (a beszélö) akaratiságának és hatóerejének mértéke nagy, a hallgatóé kicsi. Az esemény célra irányul, a cél a figyelemirányítás, valamilyen tartalom interszubjektív figyelmi előtérbe helyezése, a hallgató mentális állapotának megváltoztatása. A jelenetbeli esemény egésze aktív.

A mond ige imperfektív, időben határolatlan, megszakítatlan. Eseményszerkezete hangos beszéd, célra irányuló valós idejü esemény, tartalom (fogalmi szerkezet) beszéd általi hozzáférhetővé tétele interszubjektív megértési folyamatban. A tartalom a beszélő által konstruálódik meg, a hallgató megértési folyamatával együtt.

A mond ige alapsémájában a legfontosabb vonzatok három sematikus figurában nevezhetők meg: valaki beszél, valaki mond valamit, valakinek. A beszélésnek ebben a megkonstruálásában a beszélő (a mond ige elsődleges figurája, az itt vizsgált szerkezetekben az idézö) a kiindulópont, a referenciakeret deiktikus középpontja, a mondás cselekedete ebből a nézőpontból fejeződik ki. A beszélő megszólalása egyrészt a másikra, a pillanatnyi hallgatóra irányul, akinek a beszélő a mondás tárgyára irányítja a figyelmét, akivel a közös figyelmi jelenetben együtt hozzák létre a megértést. A beszélő megszólalása másrészt a figyelem tárgyára, vagyis a mondás tárgyára, a közös figyelem középpontjában álló megkonstruált jelenetre, annak tartalmára irányul. A mond igével a beszélö így magát a mondás aktusát konstruálja meg, jellegzetesen egy megnyilatkozás erejéig, tartalmában és idejében körülhatárolva.

A mond ige egyik legfontosabb mondatbeli megvalósulása a hogy kötőszós alárendelő mondat; ez a mondatkonstrukció az itt vizsgált naplók mond igéinek a megvalósulási sémája: azt mondja, hogy..., azt mondta, hogy...

A hogy kötőszós alárendelő mondat sémájának megfelelően a fömondat a beszélő nézőpontjából fejezi ki a megkonstruált jelenet cselekvőjének, vagyis beszélőjének mentális folyamatát és kommunikációs tevékenységét, az utalószó (azt) azt a mentális teret, a mondás mentális terét jelöli ki, amely kidolgozódik a mellékmondatban (Kugler 2017: 823). A fömondat fejezi ki a beszéd cselekvésértékét, kétszeresen is: egyrészt a mondás jelenetét megkonstruáló és elmondó tényleges beszélőét, másrészt a jelenetben cselekvő, megszólaló beszélőét. Ez perspektiválja és kontextualizálja a jelenetet, miközben a tudatosság szubjektuma a mondatbeli jelenet beszélöjére tevődik (Kugler 2017: 823, 831, 839). A mond ige idéző használatának modalitásának további részleteit lásd Csontos 2012: 200-1.

A mond ige mondatbeli megvalósulásának meghatározó tényezője az időbeli referenciakeret, azon belül a megértett inherens temporalitás (megértett idő) és a feldolgozó idő viszonya. A mond igét tartalmazó hogy kötőszós alárendelő mondat ugyanis a perspektívaadó fömondatban külön játékba hozza a mondás időbeli folyamatát, majd a hogy kötőszós mellékmondatban a mondás mentális terében a mondás tartalmát, amely szintén időben történő jelenetként konstruálódik meg. Mindkét elemi jelenet le van episztemikusan horgonyozva annak beszélöjéhez mint alaphoz. Ez az egymásra következő két inherens és egyúttal lehorgonyzott temporalitás kerül viszony- 
ba a mindkettőt kimondó vagy leíró beszélő és az azokat befogadó olvasó megértő műveletének időbeli folyamatával, a feldolgozó idővel.

Az itt vizsgált öt napló szerzőinek mint beszélőknek a mond igével konstruált összetett mondataiban az elbeszélő és az egyszerü múlt idő megoszlása és funkcionálása ebben a referenciális időkeretben történik meg. A referenciakeretet az észlelő és beszélő ember állítja föl. Az időbeli referenciakeret nézőpontszerkezetében az egyik kiindulópont a beszélő (a konceptualizáló) perspektívája, azon belül a beszéd ideje. A beszélő kiindulópontja időbeli referenciapont, mert a jelenet ideje a beszéd feldolgozó idejéhez van viszonyítva a lehorgonyzással. Ebből a lehorgonyzó viszonyból ered a deiktikus igeidö. A hogy kötőszós, mondást kifejező mondatban a szöveget alkotó beszélő felidéz egy másik, korábbi beszélőt, aki a mondatbeli mondás cselekvésének végrehajtójaként egy megnyilatkozásban ténylegesen elmondja, amit mond, de már idézetként. Az időbeli referenciakeret tehát egyfelől felállítja a teljes szöveg (szövegrészlet) beszélői kiindulópontját, amelyet a naplóban saját maga jelen idejüként dolgoz fel, és amelyet a napló olvasója (akár annak írója maga) később olvasván a bejegyzést egyszerre múlt idejüként és jelen idejüként ért meg, tudván hogy a bejegyzés korábban készült, de tudósítás és felidézés jellege kvázi jelen idejü a bejegyzésben elmondott, ahhoz képest korábbi eseményhez képest. Ehhez kapcsolódik a beszélő (naplóíró) által a felidézett beszélő referenciális kiindulópontja, amely temporálisan is kapcsolódik a felidézett beszélő által elmondott jelenethez, és lehorgonyzódik a beszélő (naplóíró) alapjához. Ez az alap - mint fentebb szó volt róla - a bejegyzés aktusának itt és most jelenéhez és egyúttal a napló tágabb kontextusában a bejegyzések szekvenciájához viszonyul. Az így alakuló időszerkezetnek további összetevője a kommunikációs igék itt megmutatkozó jellegzetes funkciója, amely „az idézés tényét teszi explicitté úgy, hogy mindeközben az eredeti diskurzus létrehozásának folyamatát is megjeleníti” (Csontos 2012: 196-200). A jelen tanulmány erre a részletre már nem tér ki.

A mond igét tartalmazó összetett mondatokban a referenciakeretben elsődlegesen a naplóíró és az általa felidézett beszélő interszubjektív viszonya profilálódik. Ezen a ponton válik fontossá, hogy a mond igét tartalmazó alárendelő mondatokban a mondás tartalmának, vagyis mentális terének mellékmondati kidolgozása idézet (ehhez lásd Csontos 2012; Csontos-Tátrai 2008; a mond igével kapcsolatban Csontos-Dér-Furkó 2019). A konstrukcióban az idéző rész a mondás cselekedete, az idézet ,egy meglevő és nyelvileg reprezentált esemény újrakonstruálása” (Csontos 2012: 196-204; Csontos 2016). Az újrakonstruálás az idézetnek és az idéző rész mondás cselekvésének a naplóbejegyzés referenciakeretébe helyezésével történik meg az idő szempontjából is. A jelen vizsgálat keretében az a kérdés, hogy a naplóíró mint szövegalkotó hogyan viszonyul saját beszédidejében (megértő idejében) a korábban megtörtént és általa felidézett mondás aktusának idejéhez, ezt a lehorgonyzó viszonyt hogyan konstruálja meg a magyar nyelvben rendelkezésére álló lehetőségekkel.

Az itt vizsgált naplók idéző mond igéi idéző mondatszerkezetben jelennek meg, időben lehorgonyozva. a lehorgonyzó müveletekben az inherens igeidő és a deiktikus igeidő kerül kapcsolatba. A mondat időszerkezetében az igeidők és az ige inherens 
temporalitása, valamint a mondat és a szöveg további tényezői közötti viszony szerint különböző változatok valósulnak meg (vö. Tolcsvai Nagy 2017: 440):

- az igealakokban megjelenő jelen, múlt és jövő igeidő funkciói,

- az igeidő és az alap egybeesésének és szétkülönbözésének változatai,

- a pillanatnyi diskurzustér tér-idő kontinuuma és a konstruált jelenet határoltsága,

- a jelenet hossza és a beszédidő hossza közötti viszony.

A mond igének a korpuszbeli használatára a fent bemutatott tényezők alapján a következők jellemzők.

A mond ige inherens (lexikai szintü) temporalitása határolatlan (a kezdő és a végpont kívül esik a közvetlen fogalmi hatókörön). A mondás időtartama a pillanatnyinál mindig hosszabb, a megnyilatkozás kimondásához, észleléséhez és megértéhez észlelhető időtartam (legalább egy-két másodperc) szükséges.

A mond ige a naplószövegekben megvalósult jelenetként a megértő időhöz (a naplóbejegyzés idejéhez mint beszélői referenciaponthoz) képest múlt idejü. A beszélő referenciakeretbeli perspektívájához képest kétféle alapváltozata különíthető el:

- befejezett, lezárt, eltávolított és objektivizációs múlt idő, episztemikusan nem közvetlen, a mondás felidézett cselekvésfolyamata és a naplóbejegyzés cselekvésfolyamata időbeli temporalitásának szekvenciális elemei között nincs megfelelés - ezt a múltat az egyszerü múlt idő fejezi ki a naplókban;

- folyamatos, vagyis múltbeli eseményként folyamatosan átélt múlt idő, az episztemikus közvetlenség teljes, a mondás észlelése imaginatív, szimulációs felidézése folyamatként közvetlen; a mondás felidézett cselekvésfolyamata és a naplóbejegyzés cselekvésfolyamata időbeli temporalitásának szekvenciális elemei között van megfelelés, mintha a múltbeli jelenetet a bejegyzés jelen idejének folytonosságában idézné fel, grammatikailag jelzett nagyfokú szubjektivizációval - ezt a múltat az elbeszélő múlt idő fejezi ki a naplókban.

A fenti áttekintés és az adatok alapján látható, hogy mind az öt naplóban a mond ige (és többnyire a kommunikációs igék) elbeszélő múltja hangsúlyos helyet kap a naplók nyelvi, diszkurzív konstruáló müveleteiben. Az elbeszélő múlt idejủ alakok további variabilitást mutatnak. A változatosság függ a bejegyzés és az idéző fömondat viszonyától: milyen mértékig közvetlen eleme a mondás az elbeszélt epizódnak, vagy sem. Függ attól, hogy a naplóíró mennyire azonosul a naplóíró által megidézett idéző beszélő nézőpontjával időben is, vagy mennyire magára az idézetre összpontosít. A változatok megkonstruálásában szerepe van az azt utalószó és a hogy kötőszó explicit használatának vagy ellenkezőleg, kerülésének: a jelölt használat inkább az objektivizáltságot erősíti, az utalószó és a kötőszó kerülése szubjektivizáltabb szerkezetet eredményez, amelyben az idézés a függő beszédre (bár ez kötőszóval is lehetséges), sőt szabad függő beszédre kezd hasonlítani, a naplóíró és az idéző beszélő beszédének temporális és perspektivikus közelségével vagy összeolvadásával. 
A (8)-ban a bejegyzés egy befejezett eseménnyel kezdődik (feljött és ott van), majd a beszélgetés felidézése során az olvasám és a mondá a beszélgetés folyamatos, jelenléti, episztemikus közvetlensége és az elbeszélés folyamatában az idézés lezáratlansága ${ }^{2}$ válik meghatározóvá. Vagyis míg az epizód elbeszélése olyan igékkel történik meg, amelyeknek kezdő- vagy végpontja az ige aktuális jelentésének közvetlen szemantikai hatókörén belül van, addig az idéző mondásige múlt időben is folyamatos aspektusú, a kezdö- és végpont nincsen profilálva.

(8) Mihelyt feljött, olvasám neki a levelet, magyarázatokat tett rá, még azt is mondá, ,szeretném tudni az ilyen kettős barátság egyez-e az emberi természettel?" (Tóth, 1836. télelő [december] 6.)

A (9)-ben és a (10)-ben a naplóíró körüli egy-egy esemény elbeszélése olvasható, egyszerü múlt időben, bár mindkettőnek jelen idejü a bevezetése, ehhez kapcsolódik a (10)-ben a kenyérlopás drámai kifejlet előtti mozzanatainak élő közvetítést felidéző jelen ideje. Maga a két történet azonban alapvetően objektivizáló, eltávolító múlt időben van megkonstruálva. Ebbe hoz pillanatnyi változást a mond elbeszélő múlt idejü alakja, amely az idézett megszólalás közvetlenségét, a beszéd közvetlen észlelését és megértését profilálja a történetben.

(9) [...] robajjal fut a szónoksegéd, ,jertek, nálam van Fekete Mátyás” (kékesi plebanus). Öltöztünk s mentünk. Alant kezdett a beszéd s fölhágott az örök eröre, Krisztusra, szóval a vallás legfölebb tárgyira. Mondá ö, hogy ezekhez hit kell, én óh, bizonyosan az kellene [...] (Tóth, 1836. nyárhó [július] 24.)

(10) Senkiről jobban el nem lehet mondani, mint Jelenfiről, hogy hasa istene. [...] Ő társaságunkban az ellökő erő. No de az ilyet is jó ösmerni! Nyikos neheztelt, hogy hova lesz nálam a kenyér? mert ő is részvényes hozzá. Mondám, vidd el mi téged érdekel belőle, én semmiről nem tehetek. Jelenfi mindent hallott, ez ebédnél volt, s négy óra után feljön, elökeresi a nehezen zsugorgatott kis darabot, $\mathrm{s}$ nem nézve rám, nem Nyikosra, nem a szegény Ferkőre, - pedig nekik van honn - kegyetlenül megette. (Tóth, 1836. őszutó [november] 28.)

A (11)-ben Bártfay László az 1838. március 13-i nagy pesti árvíz estéjének félbeszakadt bejegyzésében a városbeli eseményeket kettős nézőpontban konstruálja meg. A saját cselekvéseit elbeszélő múltban mondja el, a személyesség szubjektivizációs keretében, a tudatosság szubjektumának jelzett szerepében, az események újra átélt folyamatosságában. A külső eseményeket ellenben egyszerü múlttal fejezi ki (a napi bejegyzés itt nem idézett további legtöbb részében is). Az itt idézett részletben Wesselényi Miklós cselekedeteire vonatkoznak az egyszerü múlt idős igealakok. Ebben hoz pillanatnyi váltást a mondá, Wesselényi megnyilatkozása, amely ugyan episztemikusan közvetlen, de a gyorsan egymásra következő lezárt cselekvések so-

2 Ezt az értelmezést Csontos Nórának köszönöm. 
rába illeszkedik, ezért közvetlensége és a felidézés és a felidézett folyamata közötti megfelelés kontextuálisan kisebb mértékü, a naplóíró Bártfay és a beszélő Wesselényi közötti interszubjektív viszony a háttérben marad.

(11) A' legszelidebb holdvilágos estve volt: de a' harangok folyvást zúgtak. Vizet sehol sem látva, szokott utamon, a' Muzeum mellett, fütyülve jövék haza. B[áró]. Wesselényi Miklóst már itthon találtam. Ő valamivel korábban hagyá el a' színházat. Velünk vacsorált valami keveset. Annakutána mindjárt átküldött a' köztelekre, hol lovainak istallója volt, egyet megnyergeltetett, és ellovagolt az áradás' jelenségeit, irányát, terjedését a' városon mindenfelé vizsgálandó. Azt mondá, majd hírt hoz ha visszajö. Lefekvénk, nyugottan, mint máskor. Szokásom ágyban olvasni. Olvastam ekkor is, sokáig: részint mivel érdekes könyvet kaptam e' napokban „Napoleon und der Herzog von Vicenza" német fordításban, részint a' Bárót 's annak híreit várva. De az éjfélig nem jött vissza. Hallám a' tizenkettőt ütni, gyertyámat eloltám 's elaludtam. (Bártfay, 1838. március 13.)

A (12)-ben Kölcsey Ferenc a napkönyv (az országgyülési beszédek kivonatos jegyzőkönyve és nyilvánosságra hozatala) bevezetésének vagy bevezetése elutasításának országgyülési küzdelméből egy napi epizódot foglal össze. A jegyzőkönyvet ellenzők cselekedeteit elöször egyszerü múltban említi Kölcsey: „nem akartak emlékezni”. Ezt a képviselői cselekvést folytatja a naplóíró elbeszélő múltban: „Azt mondák”. És az esemény rákövetkező részének rögzítése szintén elbeszélő múlt időben és tárgyatlan alakban van („Hiában monda Pázmándy”), sőt az érvelés jelen idejü (egyszerre a napkönyv megvalósítása szándékának és a naplóírásnak a jelen idejében), maga az országgyülési epizód egyszerü múlt időben záródik le: „Mindezek nem használtak”. E példában tehát az elbeszélő múlt alig különbözik az egyszerủ múlt lehorgonyzó tartalmától, bár a mondás és a mondás befogadása folyamatjellegét kiemeli.

(12) Most tehát hogy a napkönyvet, amennyire lehetséges, a szerkesztők szabadkéjủ csonkításaitól megmentsük, az alnádor által ajánlott záradék ellen viadalra szállánk, és nyertesek maradánk. De e nyereséget a napkönyvi kivonat felett támadt harcban kétszeresen vesztettük el. Embereink a január 10-diki végzésre, minélfogva a kivonat megállíttaték, nem akartak emlékezni. Azt mondák: nekik s küldőiknek nem napkönyvi kivonat, hanem újság kell. Hiában monda Pázmándy, miképpen e kivonat nem akar az újság surrogatuma lenni, miképpen az újság iránt jogainkat fenntartjuk, $\mathrm{s}$ most csak egy lépést akarunk a nagyobb publicitás felé stb. Mindezek nem használtak; a magyarnak vagy a kellett amit ő akart, vagy semmi sem. (Kölcsey Ferenc, 1833. május 18.)

\section{6. Összefoglalás}

A tanulmány öt, 19. századi, reformkori napló szövegében elemezte az egyszerủ és az elbeszélő múlt idejü igealakok megoszlását a mond ige használatában. 
Az adatokból az derül ki, hogy a mond igét (és általában a kommunikációs igéket) a naplóírók döntő többségben elbeszélő múltban horgonyozzák le, általában hogy kötöszós tartalomkifejtö összetett mondatok fömondataként, a mellékmondatban a mondás által újrakonstruált idézettel. A mond igének ez az erősen szubjektivizált használata a naplóbejegyzés szövegében episztemikus közvetlenséggel fejezi ki a naplószöveg egyik szereplőjének a nyelvi tevékenységét, a beszéd vagy a naplóíró részvételével lezajlott beszélgetés átélő, részvételi, tanúsági bemutatásával. E konstruálási mód egyúttal a folyamatos jelleget is profilálja, az idézés elbeszélt múltbeli cselekedetének szimulációs felidézése közvetlen folyamatként konstruálódik meg; a mondás felidézett cselekvésfolyamata és a naplóbejegyzés cselekvésfolyamata időbeli temporalitásának szekvenciális elemei között van megfelelés. A mond igének ez a meglehetösen következetes használata a felidézett kommunikációs helyzet és a naplóírás kommunikációs helyzete közötti szoros összefüggést mutatja, szemben a más jellegủ eseményeknek a korpuszban gyakran egyszerü múlttal kifejezett temporalitásával.

\section{FORRÁSOK}

Bártfay László Naplói. Ráció Kiadó, Budapest, 2010.

Kölcsey Antónia Naplója. Bevezetéssel kiadta Kozocsa Sándor. Rózsavölgyi és Társa kiadása, Budapest, 1938.

Kölcsey Ferenc: Országgyülési napló. In: Válogatott művei. Szépirodalmi Könyvkiadó, Budapest, 1975, 673-924.

Slachta Etelka soproni úrileány naplója 1838-1840. Mediawave Alapítvány, Győr, 2014.

Tóth Péter: Napló 1836-1842. Magvető Könyvkiadó, Budapest, 1984.

\section{SZAKIRODALOM}

E. Abaffy Erzsébet 1992. Az igemód- és igeidőrendszer. In: Benkő Loránd (szerk.) A magyar nyelv történeti nyelvtana II/1. Budapest, Akadémiai Kiadó, 120-83.

Csontos Nóra 2012. Az idézés kognitív szemantikai megközelítése. In: Tolcsvai Nagy Gábor - Tátrai Szilárd (szerk.): Konstrukció és jelentés. Tanulmányok a magyar nyelv funkcionális kognitív leírására. ELTE, DiAGram Funkcionális nyelvészeti mühely, Budapest, 195-210.

Csontos Nóra 2016. Az idézés mint újrakonstruálás. Az idéző tevékenység az egyenes idézésben. Jelentés és Nyelvhasználat 3: 1-19. https://doi.org/10.14232/jeny.2016.1.1

Csontos Nóra - Tátrai Szilárd 2008. Az idézés pragmatikai megközelítése (Az idézési módok vizsgálatának lehetőségei a magyar nyelvű írásbeliségben). Általános Nyelvészeti Tanulmányok XXII: 59-119.

Csontos Nóra - Dér Csilla Ilona - Furkó Péter 2019. Idézés - önidézés - 'én'-idézés. A mondom szerepe az idézés jelölésében. Magyar Nyelvör 143: 481-94.

Kocsány Piroska 1996. A szabad függő beszédtől a belső monológig. In: Szathmári István (szerk.): Hol tart ma a stilisztika? Nemzeti Tankönyvkiadó, Budapest, 329-48.

Koselleck, Reinhart 2003. Elmúlt jövő. A történeti idők szemantikája. Atlantisz, Budapest.

Kugler Nóra 2013. A szubjektivizáltság mutatói. Magyar Nyelvőr 137: 8-30. 
Kugler Nóra 2017. Mondattan. A mondattípusok részletes tárgyalása. Az összetett mondat. In: Tolcsvai Nagy Gábor (szerk.): Nyelvtan. Osiris Kiadó, Budapest, 761-895.

Langacker, Ronald W. 2006. Subjectification, grammaticalization, and conceptual archetypes. In: Athanasiadou, Angeliki - Canakis, Costas - Cornillie, Bert (eds.): Subjectification. Various paths to subjectivity. Mouton de Gruyter, Berlin-New York, 17-40.

Langacker, Ronald W. 2008. Cognitive Grammar. A Basic Introduction. Oxford University Press, Oxford. https://doi.org/10.1093/oxfordhb/9780199544004.013.0005

Mohay Zsuzsanna 2018. Múltidö-használat a középmagyar korban. A múlt idök középmagyar kori funkcióinak vizsgálata. PhD-értekezés. ELTE, Budapest.

Sanders, José - Spooren, Wilbert 1997. Perspective, Subjectivity, and Modality from a Cognitive Linguistic Point of View. In: Liebert, Wolf-Andreas - Redeker, Gisela Waugh, Linda (eds.): Discourse and Perspective in Cognitive Linguistics. John Benjamins, Amsterdam-Philadelphia, 85-112. https://doi.org/10.1075/cilt.151.08san

Simon Gábor 2017. Áttekintés a műfajkutatás tendenciáiról és lehetőségeiről. Útban egy kognitív szemléletü müfajelmélet felé. Magyar Nyelv 113:146-66. https://doi.org/10.18349/ MagyarNyelv.2017.2.146

J. Soltész Katalin 1957. Az elbeszélő múlt kihalása. Magyar Nyelv 53: 127-38.

Stukker, Ninke - Spooren, Wilbert - Steen, Gerard 2016. Genre in language, discourse and cognition: introduction to the volume. In: Stukker, Ninke - Spooren, Wilbert - Steen, Gerard (eds.): Genre in Language, Discourse and Cognition. Mouton de Gruyter, BerlinBoston, 1-12. https://doi.org/10.1515/9783110469639-002

Szegedy-Maszák Mihály 2002. Müfajok a kánon peremén - napló és level. Palimpszeszt 17. Palimpszeszt (elte.hu).

Taavitsainen, Irma 2004. Genres of secular instruction: A linguistic history of useful entertainment. A Journal of English and American Studies 29: 75-94.

Tátrai Szilárd 2017. Pragmatika. In: Tolcsvai Nagy Gábor (szerk.): Nyelvtan. Osiris Kiadó, Budapest, 899-1058.

Tolcsvai Nagy Gábor 2006. A szövegtipológia megalapozása kognitív nyelvészeti keretben. In: Tolcsvai Nagy Gábor (szerk.): Szöveg és típus. Szövegtipológiai tanulmányok. Tinta Kiadó, Budapest, 64-90.

Tolcsvai Nagy Gábor 2017. Jelentéstan. In: Tolcsvai Nagy Gábor (szerk.): Nyelvtan. Osiris Kiadó, Budapest, 207-466.

Z. Varga Zoltán 2020. Naplóirodalom és önéletírás-kutatás. In: Böhm Gábor - Czeferner Dóra - Fedeles Tamás (szerk.): Pécsi Tudományegyetem Bölcsész Akadémia 4. Bölcsész Akadémia, Pécs, 329-57.

\section{Tolcsvai Nagy Gábor egyetemi tanár}

ELTE BTK Mai Magyar Nyelvi Tanszék

UKF Magyar Nyelv- és Irodalomtudományi Intézet https://orcid.org/0000-0002-1780-3710 


\section{SUMMARY}

\section{Tolcsvai Nagy, Gábor}

\section{Mondá - mondta. The construal patterns of the imperfective and the simple past tense in $19^{\text {th }}$ century Hungarian diaries}

The paper analyses the distribution of the finite verbs in imperfective or simple past tense in five Hungarian diaries written in the 1830s and 1840s. The investigation is focused on the verb mond 'say, tell'. This verb is construed in the corpus almost exclusively in the imperfective past tense, usually as the main (matrix) clause, with a reconstrued quotation by the act of saying in a subordinate clause, with the hogy 'that' conjunction. This highly subjectivized use of mond 'say, tell' in the entries of the diaries perspectivizes the linguistic activity of a participant with epistemic immediacy. The quoting act is evoked from a participatory, witnessing perspective by the diary writer. This simulative perspective profiles the narrated quoting as an ongoing continuous process through the imperfective past, while the simple past tense expresses events completed prior to the processing time. This type of construal shows the close and dynamic relation between the diary communication situation and the evoked quoting situation, in contrast with other activities described often in the simple past tense in the diaries.

Keywords: diary, immediacy, imperfective past, past, simple past, temporality, wittnessing

\section{A neki az ő élete szerkezettípus a -nak/-nek rag grammatikalizációjában ${ }^{1}$}

\section{Bevezetés}

A tanulmány egy különleges szerkezettípussal foglalkozik a -nak/-nek rag jelentésszerkezetében, különös tekintettel a szerkezettípus szerepére a rag grammatikalizációjában. A tanulmány címében is bemutatott szerkezettípus abban különleges, hogy a birtoklás háromszorosan is jelölt: a szintagma alaptagján birtokos személyjellel (élet-e), illetve a birtokos személyére két névmás is utal: egy datívuszi esetalakban álló (neki) és egy alapalakú (ö) személyes névmás.

A vizsgálat fó kérdése az, hogy ez a konstrukció milyen kapcsolatban van a rag jelentésszerkezetében előforduló további funkciókkal, illetve hogy milyen kapcsolódási pontot nyújt a jelentéskiterjesztődésben további funkciók felé. A kutatás korpuszalapú, ehhez elsősorban az Ómagyar Korpuszt használtam, kiegészítésként azonban felhasználtam egyéb történeti (TMK, MTSZ) és kortárs (MNSZ2) szövegadatbázist is.

1 Az Innovációs és Technológiai Minisztérium ÚNKP-20-3 kódszámú Új Nemzeti Kiválóság Programjának a Nemzeti Kutatási, Fejlesztési és Innovációs Alapból finanszírozott szakmai támogatásával készült. 